\title{
Attorney Discipline and the California Supreme Court: Transfer of Direct Review to the Courts of Appeal
}

With the growing importance of law im our society has come a sharp increase both in the workload of the courts ${ }^{1}$ and the number of attorneys charged with not neeting the ethical standards of the legal profession. ${ }^{2}$ Despite its heavy caseload, the California Supreme Court hears all but the most minor attorney disciplinary actions. The court assumed this role at a time when both the number of attorneys in California and the court's workload were much sinaller than they are today. $^{3}$ Yet the court has continued to liear disciplinary actions at the expense of its basic function of overseeing the development of California law. The wisdom of this practice is doubtful im view of the importance of the many legal questions that the suprenie court is unable to review.

This Comment argues that maintaining the integrity of the legal systen does not require the supreme court to directly review ${ }^{4}$ attorney discipline cases. Accordingly, this Comment proposes that disciplinary matters be transferred to the California Courts of Appeal. This transfer would allow the supreme court to spend more time overseeing the development of the law of California, while retaining its power to review disciplinary nuatters when appropriate.

1. National Center for State Courts, Appellate Courts: Staff and Process in THE CRISIS of Volume 2-6 (1974); 1983 Jud. CounCIL CAL. ANN. Rep. 77. "Supreme court filings reached an all-time high in fiscal year 1981-82." Id. "Filings of contested mattcrs in the Courts of Appeal decreased by 273 (-1.8 percent) from the previous year, the first decrease in recent history." Id. at 83. The number of civil filings in California superior courts has increased from 386,765 in fiscal year 1972-1973 to 532,190 in fiscal year 1981-1982. Id. at 98. Professor Preble Stolz has stated that the increase in caseload has been particularly dramatic in the highest state courts. P. STolz, JudGING Judges 2-3 (1981).

2. The state bar opened 6357 files for investigation in disciplinary matters in 1980. In 1982 the number of files opened increased to 7770. Letter from the State Bar of California to Richard Wallace (Mar. 10, 1983) (on file with the California Law Review).

3. The present system of attorney discipline was adopted in 1927 with the enactment of the State Bar Act. Act of Mar. 31, 1927, ch. 34, 1927 Cal. Stat. 38. When the state bar was organized under the Act, there were approximately 11,000 attorneys in California, K. ARNOLD, CALIFORNIA COURTS AND JUDGES HANDBOOK §4.47A, at 45 (3d ed. 1979), and the supreme court had 1358 "uncalendared" cases, 1927 JUd. Council CAL. ANN. Rep. 15.

4. The term "direct review" will be used to refer to the initial judicial review of a nonjudicial action. 
Part I of this Comment describes the appellate systein in California, and outlines the procedure that disciplinary actions follow. Part II enumerates the justifications given for the current practice of supreme court review of disciplinary actions, concluding that these justifications do not support the practice. Part II goes on to demonstrate that the factual nature of disciplinary cases niakes thein inappropriate for suprenie court review. Part III details the transfer authority of the California Supreme Court, and proposes that the court transfer disciplinary cases to the courts of appeal.

\section{I \\ The CuRrent System}

\section{A. An Overview of the California Appellate Courts}

Appellate review serves two basic functions. ${ }^{5}$ The first is to do justice between the parties by correcting mistakes made during trial. ${ }^{6}$ The second is to supervise the development of the law by instructing other judges, lawyers, and the public about the law. ${ }^{7}$

In California there are two appellate courts: the courts of appeal and the supreme court. The courts of appeal have appellate jurisdiction over unost cases in which a superior court has rendered a final judgment, ${ }^{8}$ the major exception being when the trial court lias imposed a death sentence. ${ }^{9}$ The responsibility of the courts of appeal is to correct errors made at the trial court regardless of the legal significance of the matter to anyone other than the parties. ${ }^{10}$ Since the courts of appeal have jurisdiction over inany novel issues, their decisions inevitably develop the law, but their primary purpose is to ensure a just and correct result.

In contrast, the most important function of the California Supreme Court is to oversee the developinent of California law. This task, which consists essentially of reviewing the decisions of the courts of appeal, is largely a function of its jurisdiction. ${ }^{11}$ Aside from certain

5. Joiner, The Function of the Appellate System, in Justice IN THE STATes 102 (W. Swindler ed. 1972); see also National Center for State Courts, THE California Courts of APPEAL 32 (1974) (courts perform "institutional" review, which develops the law, and "review for correctness," which corrects errors made at the trial level).

6. Joiner, supra note 5, at 102 .

7. Id.

8. CAI. Const. art. VI, $\S 11 ;$ CAL. Civ. Proc. Code $\S 904.2$ (West Supp. 1983).

9. CAL. Const. art. VI, § 11; CaL. Penal CODE § 1239(b) (West 1982). Another exception is for judgments of contempt. CAL. CIv. Proc. CODE $\$ 1222$ (West 1982).

10. Comment, Case Dispositions by the California Supreme Court: Proposed Alternatives, 67 CALIF. L. Rev. 788, 788 (1979).

11. National Center for State Courts, supra note S, at 32. See People v. Davis, 147 Cal. 346, 81 P. 718 (1905); Comment, supra note 10, at 797. See generally 6 B. WITKIN, CaLIFOR- 
exceptions noted below, ${ }^{12}$ the jurisdiction of the supreme court is purely discretionary. The court generally grants a writ of review "where it appears necessary to secure uniformity of decision or the settlement of important questions of law." 13 In addition to granting a writ of review, the supreme court fulfills its supervisory function by decertifying opinions of the courts of appeal, thus eliminating the decision as a precedent without having to hear the case. ${ }^{14}$

The supreme court also hears certain cases for reasons that are not primarily a matter of supervismg the development of California law. It may transfer a case to itself from a court of appeal when prompt resolution of the case by the supreme court is in the public interest. ${ }^{15}$ The court also directly reviews certain types of cases that the courts of appeal do not hear: criminal cases in which a death sentence has been imposed, ${ }^{16}$ matters concerning the Public Utilities Commission, ${ }^{17}$ and state bar matters. ${ }^{18}$

If the supreme court does not a grant a writ of review or decertify an erroneous decision of a court of appeal, the supreme court may have to wait a long time for another opportumity to correct the error. ${ }^{19}$ Moreover, even though the courts of appeal are divided into districts, the decisions of one district are generally followed by the other districts. $^{20}$ Fimally, the longer a legal principle is estabhshed, the less

NIA PROCEDURE Appeal $\$ \$ 607-610$, at 4532-35 (2d ed. 1971) (grounds for hearing by the supreme court).

12. See infra text accompanying notes 15-18.

13. CAI. CT. R. 29(a).

14. The constitution of California gives the supreme court the authority to determine which opinions of the supreme court and courts of appeal will be published. CAL. Const. art. V1, § 14. California Rule of Court 976(b) provides the criteria for determining which opinions of the courts of appeal nnay be published. CAL. CT. R. 976(b). If the majority of the court rendering the opinion certifies that the opinion meets the criteria of $976(\mathrm{~b})$ then the opinion is published. CAL. $C_{T}$. R. 976(c)(1). However, the supreme court may order that any opinion which has been certified for publication not be published. CAL. CT. R. 976(c)(2). "Decertification" thus refers to this procedure whereby the supreme court orders a court of appeal opinion previously certified for publication to be "unpublished." For a fuller explanation and defense of decertification, see Grodin, The Supreme Court of California, 1983-1984 Foreword (forthcoming in volume 72 of the California Law Review).

15. CAI. Const. art. VI, § 12; see, e.g., Brosnahan v. Brown, 32 Cal. 3d 236, 241, 651 P.2d 274, 276, 186 Cal. Rptr. 30, 32 (1982) ("It is uniformly agreed that the issues are of great public inuportance and should be resolved promptly. Accordingly, under well-settled principles, it is appropriate that we exercise our original jurisdiction.").

16. The constitution of California gives the supreme court jurisdiction in all cases in which the death penalty is imposed, and the Penal Code requires an appeal in all such cases. CaL. Const. art. VI, § 11; CAL. PENAL CODE § 1239(b) (West 1982). The supreme court therefore has original jurisdiction in all such cases.

17. CaL. Pub. UTHL. CODE $\$ \$ 1756,1759$ (West 1975).

18. CAL. Bus. \& Prof. CoDe $\S \S 6066,6078,6081-6082,6084$ (West 1974).

19. P. StOLz, supra note 1, at 196.

20. See, e.g., Swinerton \& Walberg Co. v. Inglewood-L.A. County Civic Center Auth., 40 Cal. App. 3d 98, 101, 114 Cal. Rptr. 834, 835-36 (1974) (while noting that it is not bound to follow 
likely it is to be challenged. Thus, the first holding by a court of appeal on an issue of law will usually becoine the law of California unless that case is reviewed and modified by the supreine court. ${ }^{21}$

There are six districts in the California Courts of Appeal, with a total of seventy-seven judges. ${ }^{22}$ The work of the courts of appeal has increased substantially since fiscal year 1970-1971, when they handled 8327 inatters and issued 3813 opinions. $^{23}$ In the fiscal year 1980-1981, before the addition of eighteen judges and a sixth district, the courts of appeal handled 14,972 contested matters and issued 7166 written opinions. ${ }^{24}$ In 1982, the publislied opinions of these courts filled more than 12,000 pages in eleven volumes of the California Appellate Reports. ${ }^{25}$ Witl the addition of eighteen new judges in 1982, the output of the courts of appeal should continue to grow. ${ }^{26}$

The increasing number of decisions from the courts of appeal has led to greater demands on the supreme court. The number of petitions for hearing filed with the supreme court has risen with the number of decisions filed by the courts of appeal. ${ }^{27}$ While inuch of the screening process may be handled by the court's staff, ${ }^{28}$ the growing number of

a decision of the Third District, the court nonetheless followed it, stating that it found the rationale persuasive). See also In re Ruth H., 26 Cal. App. 3d 77, 86, 102 Cal. Rptr. 534, 539 (1972) (while noting that the conclusions of two other courts in another division were apparently based on an artificial distinction, the court nonetheless followed them, because it felt "obligated to avoid conflict with another division of [the] district"); P. STOLZ, supra note 1, at 196; 6 B. W1TKIN, supra note 11 , Appeal $\$ 667$, at $4580-81$.

21. P. Stolz, supra note 1 , at 196.

22. CaL. Gov't CODE $\$ \S 69100-69106$ (West 1976 \& Supp. 1983). See generally $\mathrm{K}$. ARNOLD, supra note $3, \S 2.8$, at $8-9$.

23. 1974 Jud. Council Cal. ANN. Rep. 65 table VI, 71 table VIII.

24. 1983 Jud. Council CAL. ANN. REP. 51 table VI, 89 table VII.

25. Published opinions for 1982 begin at page 514 of volume 127 and continue through page 883 of volume 138 of the third series of California Appellate Reports.

26. See K. ARNOLD, supra note $3, \$ 2.8$, at 1-2.

27.

Petitions for hearing Granted by California Supreme Court Petitions for Hearings
Froin Courts of

Appeals Decided by

\begin{tabular}{lccc} 
Year & $\begin{array}{c}\text { Opinion in Courts } \\
\text { of Appeal }\end{array}$ & $\begin{array}{c}\text { Froin Courts of } \\
\text { Appeals }\end{array}$ & Percent \\
\cline { 2 - 3 } $1972-73$ & 3,890 & 1,457 & 37.5 \\
$1973-74$ & 4,389 & 1,686 & 38.4 \\
$1974-75$ & 5,240 & 1,901 & 36.3 \\
$1975-76$ & 5,592 & 2,310 & 41.3 \\
$1976-77$ & 5,626 & 2,263 & 40.2 \\
$1977-78$ & 5,686 & 2,356 & 41.4 \\
$1978-79$ & 5,750 & 1,912 & 33.3 \\
$1979-80$ & 6,175 & 2,044 & 33.1 \\
$1980-81$ & 6,633 & 2,057 & 31.0 \\
$1981-82$ & 7,283 & 2,069 & 28.4
\end{tabular}

1983 JUd, Council CAL. ANN. Rep. 81 table III-A.

28. For an explanation of how the suprene court has used its staff to liandle the increased workload, see Goodman \& Seaton, The Supreme Court of California, 1972-1973-Foreword: Ripe 
petitions either adds to the work of the justices or increases their dependence on their staffs. The sheer number of decisions from the courts of appeal makes the task of promoting uniformity of the law throughout the state more difficult. Finally, the courts of appeal generate an enormous number of opinions ${ }^{29}$ that only the supreme court can review. Despite these increased demands, the court's basic resource-seven justices-has remained constant, causing the court to become increasingly selective in granting writs of review. ${ }^{30}$

It has been suggested that the California Supreine Court has reached the upper limit of the amount of work it can do. ${ }^{31}$ In fiscal year 1981-1982, the court considered 3366 petitions for hearing, granted 280, and wrote 123 opinions. ${ }^{32}$ Grants of review, original proceedings, and, especially, written opinions require the attention of the justices. While larger staffs and inore efficient procedures can help, ${ }^{33}$ the burden must ultimately fall on the justices. Against this backdrop, a reexamination of the direct review of cases not connected to the supreme court's function of guiding the development of Califorma law becomes necessary.

\section{B. The Supreme Court's Supervision of the Bar}

In inost states the highest state court maintains ultimate control over admission to the bar. ${ }^{34}$ In addition to its power to admit attorneys to the bar, ${ }^{35}$ the California Supreme Court has long stated that it has the inherent power to discipline attorneys. ${ }^{36}$ Although the court has

for Decision, Internal Workings and Current Concerns of the California Supreme Court, 62 CALIF. L. REV. 309, 312-13 (1974).

29. See supra note 27.

30. In 1971-1972, the California Supreme Court granted 230 petitions for hearing, or $9.5 \%$ of the petitions filed. In 1980-1981, the court granted 267 petitions for review, or $8.4 \%$ of the petitions filed. 1982 Jud. Council Cal. AnN. Rep. 49 table IV.

31. P. STolz, supra note 1, at 3, 194; Special Committee re Appellate Courts, The Court of Review: A New Court for California?, 47 CAL. ST. B.J. 28, 28-29 (1972); Comment, supra note 10, at 789-91. But see Mosk, The Supreme Court of California, 1973-1974-Foreword: The Rule of Four in California, 63 CALIF. L. REv. 2, 7-8 (1975) (though the workload of the court is heavy, the court is not "bursting at the seams").

Justice Mosk has recently advocated a constitutional amendment to add four justices to the California Supreme Court and to split the court into civil and criminal divisions. The object of Justice Mosk's proposal is "[t]o handle the current and future caseload." Mosk, A Two Part Supreme Court, L.A. Times, June 29, 1983, § 2, at 5, col. 3.

32. 1983 Jud. Council Cal. ANN. Rep. 80 table II, 81 table IV.

33. For a discussion of the internal workings of the California Supreme Court and its staff, see Goodman \& Seaton, supra note 28.

34. aba Special Comm. on Evaluation of Disciplinary Enforcement, Problems AND ReCOMMENDATIONS IN DisciplinaRy ENFORCEMENT 10 (1970) thereinafter cited as ClaRK REPORT].

35. See infra text accompanying notes 61-63.

36. See Stratmore v. State Bar, 14 Cal. 3d 887, 889, 538 P.2d 229, 230, 123 Cal. Rptr. 101, 102 (1975); Brydonjack v. State Bar, 208 Cal. 439, 443, 281 P. 1018, 1020-21 (1929). 
acknowledged that the legislature has a legitimate role in setting minimum standards for the bar, ${ }^{37}$ the court has repeatedly held that the statutory grounds for discipline are not exclusive. ${ }^{38}$

In disciplinary matters, the California Supreme Court follows the pattern established by the State Bar Act. ${ }^{39}$ Before the adoption of the Act in 1927, discipline of attorneys was handled exclusively by the courts. ${ }^{40}$ Power to discipline was held not only by the supreme court, but by the district appellate courts as well. ${ }^{41}$ The State Bar Act codified the supreme court's practice of transferring bar matters to itself $^{42}$ by means of the transfer authority of the California Constitution. ${ }^{43}$

The State Bar Act authorizes the state bar to conduct investigations and hearnigs regarding attorney misconduct, and provides the resources necessary to investigate and judge the merits of the thousands of complaimts filed against attorneys in California each year. ${ }^{44}$ The disciplinary work of the state bar is perforned by the State Bar Court. ${ }^{45}$ However, any person subject to discipline by the state bar or any of its committees may have the action reviewed by the supreine court. ${ }^{46}$ The State Bar Act thus places the supreme court at the apex of the disciplinary system, making it responsible for reviewing all disciplinary actions.

In two types of cases the supreine court automatically examines the record of bar court hearings and grants all petitions for writs of

37. In re Lavine, 2 Cal. 2d 324, 330, 41 P.2d 161, 162 (1935); 1 B. WitKIN, supra note 11, Attorneys § 155, at 166 .

38. Stratmore v. State Bar, 14 Cal. 3d 887, 889, 538 P.2d 229, 230, 123 Cal. Rptr. 101, 102 (1975).

39. The State Bar Act established a complete system of attorney discipline, but the provisions of the Act are "a complete alternative and cumulative method of hearing and determining accusations against members of the State Bar." CAL. Bus. \& Prof. Code $\$ 6075$ (West 1974). Thus, the Act does not "limit] or alter[] the powers of the Supreme Court . . . to disbar or discipline members of the bar." Id. $\S 6087$.

40. 1 B. WITKIN, supra note 11, Attorneys $\S 186$, at 193.

41. Act of Mar. 24, 1874, ch. 383, $\S 21,1873-74$ Cal. Stat. 278, 289-90, repealed by Act of Feb. 3, 1939, ch. 34, § 2, 1939 Cal. Stat 347, 361-62.

42. See, e.g., In re Stevens, 197 Cal. 408, 417, 241 P. 88, 91 (1925); In re Wells, 174 Cal. 467, 470-73, 163 P. 657, 658-59 (1917).

43. CAL. CoNST. art. VI, § 12. See infra notes $127-35$ and accompanying text.

44. CAL. Bus. \& Prof. Code $\S \S 6075-6087$ (West 1974 \& Supp. 1983).

45. See generally Hirshberg, The New State Bar Court, 54 CAL. ST. B.J. 438 (1979) (describing the State Bar Court).

46. Section 6082 of the California Bnsmess and Professions Code states:

Any person complained against and any person whose reinstatement the board may refuse to recommend may have the action of the board, or of any committee authorized by it to make a determination on its behalf, pursuant to the provisions of this Chapter, reviewed by the Supreme Court in accordance with the procedure prescribed by the court.

CAL. Bus. \& Prof. CoDe $\S 6082$ (West 1974). 
review. ${ }^{47}$ First, when an attorney is convicted of a crime involving moral turpitude, the supreme court decides whether to impose an interim suspension, and refers the inatter to the bar court for a recommendation for permanent action. ${ }^{48}$ The supreme court then reviews the bar court's recommendation. Second, the supreine court reviews the bar court's recommendations of suspension or disbarment for violations of the rules of professional conduct ${ }^{49}$ or provisions of the State Bar Act. ${ }^{50}$

The supreme court also has discretion to review public and private reprimands, which do not require supreme court action under the State Bar Act. ${ }^{51}$ Until recently, the supreme court automatically granted all petitions for review of these cases. In January 1983, however, the court announced that it would grant review of reproval cases only when the attorney files a fully documented petition for review that makes a prima facie case for relief. ${ }^{52}$

Thus, the supreme court's supervision of attorney discipline entails direct review in thrce situations: interim suspension upon conviction of a crime involving moral turpitude, review of the bar court's recommendations of suspension or disbarment, and reprovals by the state bar. In all but the last of these situations, not only is supreme court review of the bar court record automatic, but the attorney is entitled to a hearing before the supreme court upon request.

II

Supreme Court Review of Attorney Discipline

The practice of supreme court review of disciplinary inatters is well cstabhished im California. But the increase in workload of the court makes the wisdom of this practice questionable. Section A of this Part evaluates the justifications given for the practice, and concludes that there are no strong reasons why the supreme court should directly review disciplinary inatters. Section B finds that the nature of disciplinary cases makes these cases mappropriate for supreme court review.

\section{A. The Justifications for the Supreme Court's Role}

The most important endorseinent of direct review of disciplinary

47. Alberton v. State Bar, No. S.F. 24472 (Cal. Sup. Ct. reh'g denied Jan. 6, 1983); Carrizosa, Court Discontinues Automatic Review in Reproval Cases, L.A. Daily J., Jan. 10, 1983, at 1, col. 2.

48. Cal. Bus. \& Prof. Code $\S \S 6100-6101,6102(c)$ (West 1974 \& Supp. 1983).

49. Id. $\$ 6077$.

50. Id. $\$ \$ 6103-6106.1,6127-6131$.

51. CAL. CT. R. 952(a).

52. Alberton v. State Bar, No. S.F. 24472 (Cal. Sup. Ct. reh'g denied Jan. 6, 1983); Carrizosa, supra note 47 , at 1 , col. 2. 
actions by the highest court of a state came from the American Bar Association. In 1970 the ABA's Special Committee on Evaluation of Disciplinary Enforcement published an extensive report (the Clark Report) on state disciplinary systems. ${ }^{53}$ One of the committee's strongest recommendations was "[s]tatewide centralization of disciplinary jurisdiction under the ultimate control of the highest court."54 California's present system closely resembles the Clark Report's recommendations and may have been a model for the report. ${ }^{55}$ Upon analysis, however, the possible justifications for supreme court review are not persuasive.

\section{The Need for Review}

Given the important interests involved, some form of judicial review of disciplinary actions taken by the state bar is needed. But the need for judicial review does not justify direct review by the supreme court. In California, all other professions regulate themselves without direct review of their disciplinary proceedings by the supreme court. Other professionals, such as physicians, financial planners, and psychologists do not receive such supervision even though they, like attorneys, are often im fiduciary relationships with their chents. Similarly, disciplinary actions agamst pohice officers, city managers, and other public officials are not routmely reviewed by the supreme court. With the exception of attorneys, the disciplinary proceedings of professions in California are reviewed by the superior court and may be appealed to the courts of appeal. ${ }^{56}$

\section{The Symbolism of Direct Review}

Review by the supreme court might also be justified as a symbol of society's interest in maintaiming the integrity of the judicial system. The public, however, probably has hittle awareness of the supreme court's review of attorney discipline actions. ${ }^{57}$ But to the extent that the

53. ClARK REPORT, supra note 34.

54. Id. at 24.

55. Outcault \& Peterson, Lawyer Discipline and Professional Standards in California: Progress and Problems, 24 Hastings L.J. 675, 676 (1973).

56. Section 1094.5 of the California Code of Civil Procedure has been interpreted to make administrative mandamus the proper remedy for review of final orders and decisions of an agency which exercises quasi-judicial powers affecting vested rights. CAL. Civ. Proc. Code $\S 1094.5$ (West Supp. 1983); 5 B. WrTkn, supra note 11, Extraordinary Writs $\S \S 214,219$. See Grant v. Board of Medical Quahity Assurance, 232 Cal. App. 2d 820, 827, 43 Cal. Rptr. 270, 274 (1965). Although the superior courts, the courts of appeal, and the supreme court have original jurisdiction to issue writs, CAL. CoNST. art. VI, $\S 10$, the courts of appeal and the supreme court will refuse to exercise origimal jurisdiction unless the circumstances are exceptional, see $C_{A L}$. CT. $R$. 56(a). Thus, the writ must be filed with a superior court. Generally, the petition is limited to the record of the administrative agency. 5 B. WITKIN, supra note 11, Extraordinary Writs $\$ 237$. The case is heard by a judge sitting without a jury. CAL. CIv. Proc. CODE $\S 1094.5$ (a) (West 1983).

57. Perhaps the symbolism of review by the highest court is more widely perceived among 
public is knowledgeable about the discipline of professionals, any positive symbolic value may be offset by a negative symbolism: the public could well perceive supreme court review of attorney discipline cases as cliaracteristic of a privileged profession whose members are guaranteed review before a court whose doors are usually closed not only to disciplined members of other professions, ${ }^{58}$ but to the vast majority of petitioners as well..$^{59}$

\section{The Court Granting Entrance to the Practice Should Supervise the Practice}

According to the Clark Report, "[i]t logically follows that the court having power to admit a person to the practice of law should also be the agency having jurisdiction . . . to remove his license to practice." 60 In addition to mistaking symmetry for logic, this argument assumes that the supreme court plays a significant role in admitting attorneys to the bar. In fact, lowever, while the court lias the power to admit applicants to the practice of $1 a w,{ }^{61}$ its actual role in the process is quite limited. The work of screening and testimg applicants for certification to the supreme court for admission to practice is carried out by the Committee of Bar Exammers. ${ }^{62}$ Under the State Bar Act, any applicant refused certification may appeal to the supreme court for review of the Committee's decision. ${ }^{63}$ But the number of petitions for review of admissions matters is very sinall coinpared with the number of disciplinary cases. ${ }^{64}$

the legal community, which is familiar with the disciplinary system. However, any positive effects on the legal community arising from this symbolisin must be weighed against any adverse public perceptions.

58. A lexis search on Jan. 15, 1984 of cases decided by the Cahifornia Supreme Court revealed only three cases since 1968 involving health professionals appealing disciplinary or admission actions. Franz v. Board of Medical Quality Assurance, $31 \mathrm{Cal} .3 \mathrm{~d}$ 124, 642 P.2d 792, $181 \mathrm{Cal}$. Rptr. 732 (1982); Patty v. Board of Medical Examiners, 9 Cal. 3d 356, 508 P.2d 1121, 107 Cal. Rptr. 473 (1973); Yakov v. Board of Medical Examiners, 68 Cal. 2d 67, 435 P.2d 553, 64 Cal. Rptr. 785 (1968).

59. In fiscal year 1981-1982, the supreme court granted only $8.3 \%$ of the petitions for hearing that it received. 1983 JUD. CounCIL CAL. ANN. REP. 81 table IV.

60. ClaRK REPORT, supta note 34 , at 10.

61. Id.

62. The Committee of Bar Examiners operates pursuant to CAL. Bus. \& Prof. Code $\S \S 6046-6046.5$ (West $1974 \&$ Supp. 1983).

63. Cal. Bus. \& Prof. Code $\$ 6066$ (West 1974).

64. In 1982 only two petitions for review of admissions matters were filed with the supreme court and both were denied. In re Pacheco, No. S.F. 24466 (Cal. Sup. Ct. hearing denied July 14, 1983); Cunningham v. State Bar, No. S.F. 24389 (Cal. Sup. Ct. hearing denied Mar. 25, 1982). 


\section{The Special Interest in Maintaining the Integrity of the Legal System}

Another argument in support of direct supreme court review is that the judiciary has a special interest in attorney discipline, as ethical conduct by attorneys is crucial to the integrity of the legal system. Judicial review of the state bar serves not only to protect an attorney's due process rights, but also to protect the public, the courts, and the legal profession from unqualified and unscrupulous attorneys. ${ }^{65}$ Further, as the Clark Report suggests, "public dissatisfaction with the bar and the courts is mucl more intense than is generally believed," 66 making a disciplinary system that creates public confidence in the courts essential. ${ }^{67}$

The importance of public confidence in the judicial system undoubtedly justifies a high degree of judicial scrutimy of the ethics of lawyers. However, direct and automatic review of disciplinary cases by the supreme court is not the only means of effective judicial supervision of the disciplinary process. ${ }^{68}$ Sucl review can be justified only if the supreme court is umquely qualified to hear these cases. Several arguments have been advanced to suggest that the supreme court may be peculiarly qualified to review disciplinary cases. ${ }^{69}$

\section{a. Consistency}

Fair discipline requires consistent evaluation of actions and application of penalties. As noted below, deciding on the appropriate discipline involves a factual determination. ${ }^{70}$ Because there is no set formula, ${ }^{71}$ and because each case presents many relevant factors, ${ }^{72}$ previous cases provide little guidance. ${ }^{73}$ Drawing on his own values, feelings, and experience, a judge must determine what sanction is appropriate for each particular set of circumstances. Proponents of supreme court review argue that having only one court impose all discipline is therefore the best metlod of maintaining consistency. ${ }^{74}$

Having one court hear all disciplinary matters has not, lowever,

65. See, e.g., Tenner v. State Bar, 28 Cal. 3d 202, 207, 617 P.2d 486, 488, 168 Cal. Rptr. 333, 335 (1980).

66. Clark Report, supta note 34 , at 2.

67. See id.

68. See infra notes $122-25$ and accompanying text.

69. ClaRk RePORT, supra note 34, at 10-18.

70. See infra text accompanying notes 101-15.

71. Doyle v. State Bar, 32 Cal. 3d 12, 24, 648 P.2d 942, 949, 184 Cal. Rptr. 720, 727 (1982).

72. See The Supreme Court of California, 1972-1973, 62 CALIF. L. Rev. 408, 619-20 (1974) (listing some initigating factors).

73. Id. at 612-13. "[T] which make virtually no new law." Id. at 613 .

74. See Clark Report, supra note 34, at 28. 
led to any noteworthy consistency. ${ }^{75}$ Indeed, the court has stated that "there is no conformity as to punishment ascertainable froin the cases."76 Given the number of factors involved, consistency would require either a bright-line approach to discipline, or a time-consuming comparison of the facts before the court with the records of previous cases. The court has rejected simple formulas, ${ }^{77}$ and the court's workload and the number of disciplinary cases that conne before the court make a thorough examination impractical. Moreover, even if detailed factual comparisons of this kind were feasible, they would probably add little consistency to the process. ${ }^{78}$

Finally, absolute consistency is not required in other areas of the law. In criminal sentencing, where the severity of the sanctions makes consistency especially important, there is no serious atteinpt to guarantee absolute consistency. Courts are content to ensure that the same standards are apphed to broad classes of defendants. ${ }^{79}$ Similarly, jury awards of general, specific, and punitive damages are not scrutinized for consistency. Generally, an appellate court will change an award of damages only if the evidence warrants a finding that the verdict was the result of passion, prejudice, or corruption. ${ }^{80}$ An award of damages is not erroneous as a matter of law solely because in a prior decision a different amount was awarded in similar circumstances. ${ }^{81}$ Some incon-

75. 1 B. WITKIN, supra note 11, Attorneys \& 270, at 274.

76. Yapp v. State Bar, 62 Cal. 2d 809, 819, 402 P.2d 361, 366, 44 Cal. Rptr. 593, 598 (1965); see also In re Hanley, 13 Cal. 3d 448, 452, 530 P.2d 1381, 1383, 119 Cal. Rptr. 5,7 (1975) (the rule is not uniform, and each case turns on its facts); Toll v. State Bar, 12 Cal. 3d 824, 831, 528 P.2d 35, 40, 117 Cal. Rptr. 427, 432 (1974) ("each case must be decided on its own facts").

77. Doyle v. State Bar, 32 Cal. 3d 12, 24, 648 P.2d 942, 949, 184 Cal. Rptr. 720, 727 (1982).

78. See infra notes 101-15 and accompanying text.

79. See generally E. Kennedy, Criminal sentencing: a game of chance, 60 Judicature 208 (1976) (illustrating sentencing disparity); Korbakes, Criminal Sentencing: is the Judge's sound discretion subject to review?, 59 JUDICATURE 113 (1975) (surveying availabilty of crimimal sentence review).

California has moved to imcrease the uniformity of sentences by adopting a deterninate sentencing law. Act of Sept. 20,1976, ch. 1139, 1976 Cal. Stat. 5061. As part of this Act, a court is required to inpose the niddle of three sentences set forth in the statute unless there are aggravating or mitigating circumstances. CAL. Penal Code $\S 1170(\mathrm{~b})$ (West Supp. 1983). Sentences are then reviewed by the Board of Prison Terms to determine if the sentence is "disparate in coinparison with the sentences imposed im similar cases." Id. $\S 1170(f)(1)$. If the Board deternines that a sentence is disparate, the sentencing court holds a hearing and inay reduce the sentence. Id. Finally, the Judicial Council is directed to proinote uniformity by adopting rules providimg criteria for sentencing. Id. $\$ 1170.3$. While such statutes demonstrate a concern for uniformity, they still provide for aggravating or mitigating circumstances, thereby allowing a court to tailor a sentence to imdividual culpability.

80. Schroeder v. Auto Driveaway Co., 11 Cal. 3d 908, 919-20, 523 P.2d 662, 669-70, 114 Cal. Rptr. 622, 629-30 (1974) (applying standard to claims of excessive damages); Ward v. Litowsky, 5 Cal. App. 3d 437, 440, 85 Cal. Rptr. 278, 280 (1970) (rejecting appeal claiming inadequate damage).

81. Leming v. Oilfields Trucking Co., 44 Cal. 2d 343, 356, 282 P.2d 23, 31 (1955). 
sistency in verdicts, awards, and discipline is accepted as an inevitable consequence of the multitude of factors that must be considered and weighed.

\section{b. Impartiality}

To mamtain public confidence in the judicial system, a system of attorney discipline must avoid both actual and apparent partiality. ${ }^{82}$ Accordingly, the Clark Report urged direct review of disciplinary cases by the highest state court to prevent judges from imposing discipline on attorneys who are social acquaintances or who regularly appear in their courts. ${ }^{83}$ Review by the supreme court ensures that discipline is administered by the court before which an attorney is least likely to appear. The size of the supreme court and the nature of its work minimize the effects of friendship, grudges, and familiarity.

While this argument has some inerit, the number of courts in the California court system and the size of the state bar diminisli the applicability of this argument to the California systen. First, there are currently more than 80,000 members of the bar in California. ${ }^{84}$ The courts of appeal in California consists of six appellate districts with eighteen divisions and seventy-seven judges. ${ }^{85}$ Within the courts of appeal it should not be difficult to find a panel of judges with which a particular attorney has not had frequent contact. Second, the physical size and population of California decrease the likelihood that personal contacts between lawyers and courts of appeal judges will arise outside the legal practice. Thus, in California, the need to avoid local conflicts of interest is far less compelling a reason for review by the supreine court than it is in smaller states.

\section{c. Prestige of the Court}

It can be argued that the prestige of the supreme court strengthens the impact of its review of disciplinary cases. ${ }^{86}$ The prestige of the court may impress the seriousness of the misconduct upon the disciplined attorney and increase the legal community's awareness of disciplinary cases. ${ }^{87}$ However, the rehabilitative and deterrent effects of discipline imposed by the supreme court are available through other means. Tight snpervision by the bar of attorneys on probation, disci-

82. Clark Report, supra note 34, at 28.

83. $I d$.

84. Letter from State Bar of California to Richard Wallace (Nov. 28, 1983) (on file with the California Law Review).

85. CAL. Gov't CODE $\S \S 69101-69106$ (West 1976 \& Supp. 1983).

86. The Supreme Court of California, 1972-1973, supra note 72, at 622-23.

87. Id 
pline by intermediate appellate courts, and publicity ${ }^{88}$ can all be used as alternative means of impressing upon the mdividual the need for reform without significantly diminishing the legal community's awareness of the need for attorney discipline.

\section{d. Expertise of the Court}

Another argument supporting supreme court review of disciplinary actions is that the court has acquired expertise through hearing disciplinary cases. The supreme court is now the only court with experience in disciplinary cases. However, assummg that expertise is relevant in disciplinary cases, the lack of experience of other courts should not be a serious consideration, as other courts, if given the responsibility, would soon become familiar with disciplinary matters. Dividing disciplinary cases among many courts would prevent any one court froin developing the same level of expertise as the supreme court. This diminished expertise would not be critical, lowever, given the routine nature of the cases and the supreme court's ability to review the decisions of the lower courts. ${ }^{89}$ Moreover, the courts of appeal routinely follow precedent and handle new areas of the law, and there is no reason why disciplinary cases should present any unusual difficulty.

\section{e. Minimization of Frivolous Appeals}

Simce the supreme court is the only source of judicial review in attorney disciplinary matters, the opportumity to delay sanction by bringing frivolous appeals is minimized. Imposing a layer of judicial review below the supreme court would give a lawyer a new opportunity to delay his discipline. However, if the supreme court applied the same standards for granting hearings that it uses for other cases, the court would probably deny most petitions for review in disciplinary cases. Furthermore, the imstances of delay would probably be no greater than those caused by the number of petitions now filed.

Even given a higher number of appeals, the supreme court could adopt rules to limit an attorney's imcentive to use an appeal as a dilatory tactic. The court could give priority to considering petitions for review where a lower court had imposed suspension or disbarment. In addition, the court could use its inherent power over disciplinary cases to impose an interim suspension while a petition for review was pending. While considering the petition, the court might also place petitioning lawyers on a stricter form of probation as a condition for review.

88. Currently, the names of attorneys disciplined in California are published along witl the facts surrounding the'discipline in the California Lawyer. See, e.g., Disciplined Attorneys Named, CAL. LAw., Mar. 1983, át 59.

89. See The Supreme Court of California, 1972-1973, supra note 72, at 621-22. 
Although the integrity of the bar is essential to a healthy judicial system, inost disciplinary cases have little legal significance. In contrast, the supreine court's regular cases are selected because of their importance to the law of California. There are important tasks that only the supreme court can perforn, while discipline could be handled by the courts of appeal without diminishing the quality of judicial supervision over the bar. Thus, the advantages of the supreine court's present practice do not justify its costs.

\section{B. The Nature of Disciplinary Cases}

Direct supreine court review of attorney discipline cases conflicts with its basic role of supervising the developinent of the law. In deciding these cases, the supreme court evaluates the bar court's factual determinations ${ }^{90}$ and its recommended discipline. ${ }^{91}$ The holdings in attorney discipline cases tend to be highly individualized and fact-specific. Consequently, these holdings cannot be distilled into the kind of general legal principles that serve as precedent.

Findings of fact by the bar court are not binding on the supreme court, ${ }^{92}$ as the supreme court "inust reweigh the evidence, passing on its sufficiency."93 Thus, the court independently reviews the record and often makes its own factual determinations. ${ }^{94}$ There were ten disciplinary opinions published by the supreme court in $1982 .{ }^{95}$ In six of those cases the bar court's findings of fact were at issue. ${ }^{96}$ In one of these cases, ${ }^{97}$ the court rejected the bar court's finding that the petitioner, an

90. See generally id at 615-16 (describing the effect of the supreme court's review of findings of fact).

91. See generally id. at 616-20 (describing the effect of the supreme court's review of sanctions).

92. Vaughn v. State Bar, 9 Cal. 3d 698, 701, 511 P.2d 1158, 1160, 108 Cal. Rptr. 806, 808 (1973).

93. Id.

94. Price v. State Bar, 30 Cal. 3d 537, 546, 638 P.2d 1311, 1315-16, 179 Cal. Rptr. 914, 918-19 (1982).

95. In re Mudge, 33 Cal. 3d 152, 654 P.2d 1307, 187 Cal. Rptr. 779 (1982); Dixou v. State Bar, 32 Cal. 3d 728, 653 P.2d 321, 187 Cal. Rptr. 30 (1982); Montag v. State Bar, 32 Cal. 3d 721, 652 P.2d 1370, 186 Cal. Rptr. 894 (1982); Athearn v. State Bar, 32 Cal. 3d 38, 648 P.2d 950, 184 Cal. Rptr. 728 (1982); Doyle v. State Bar, 32 Cal. 3d 12, 648 P.2d 942, 184 Cal. Rptr. 720 (1982); Gordon v. State Bar, 31 Cal. 3d 748, 647 P.2d 137, 183 Cal. Rptr. 861 (1982); In re Schwartz, 31 Cal. 3d 395, 644 P.2d 833, 182 Cal. Rptr. 640 (1982); Ambrose v. State Bar, 31 Cal. 3d 184, 643 P.2d 486, 181 Cal. Rptr. 903 (1982); Garlow v. State Bar, 30 Cal. 3d 912, 640 P.2d 1106, 180 Cal. Rptr. 831 (1982); Price v. State Bar, 30 Cal. 3d 537, 638 P.2d 1311, 179 Cal. Rptr. 914 (1982).

96. Dixon v. State Bar, 32 Cal. 3d 728, 736, 653 P.2d 321, 326, 187 Cal. Rptr. 30, 35 (1982); Montag v. State Bar, 32 Cal. 3d 721, 725, 652 P.2d 1370, 1372, 186 Cal. Rptr. 894, 896 (1982); Athearn v. State Bar, 32 Cal. 3d 38, 41, 43, 648 P.2d 950, 950, 952, 184 Cal. Rptr. 728, 728, 730 (1982); Doyle v. State Bar, 32 Cal. 3d 12, 21, 648 P.2d 942, 947, 184 Cal. Rptr. 720, 725 (1982); In re Schwartz, 31 Cal. 3d 395, 399, 644 P.2d 833, 835, 182 Cal. Rptr. 640, 642 (1982); Price v. State Bar, 30 Cal. 3d 537, 547, 638 P.2d 1311, 1316, 179 Cal. Rptr. 914, 919 (1982).

97. Price v. State Bar, 30 Cal. 3d 537, 638 P.2d 1311, 179 Cal. Rptr. 914 (1982). 
assistant district attorney, had not received valuable consideration for an agreement not to prosecute a defendant. ${ }^{98}$ In the other five cases, the court reviewed the findings of fact or the sufficiency of the evidence, but declined to make new findimgs. ${ }^{99}$

Such decisions do not develop the law. Although the supreme court has established presumptions and burdens of proof for reviewing the recommendations of the bar court, ${ }^{100}$ the supreme court must still reweigh the facts. If enough consistent disciplinary opinions are published, litigants can estiniate what proof is needed to overcome a factual finding of the bar court. Thus, the elaboration of evidentiary requirements may make a marginal contribution to the law. However, direct review of disciplinary cases does not allow the supreme court to fulfill its supervisory function of rnling on only those cases that will significantly affect the law.

Similarly, the supreine court's determination of the appropriate discipline does hittle to develop the law in California. The supreme court decides whether the recommended discipline is appropriate, ${ }^{101}$ and the court has the discretion to increase or decrease the recommended discipline. ${ }^{102}$ The type and extent of discipline is a function of the wrongfulness of the petitioner's actions, ${ }^{103}$ the need to protect society from unfit attorneys, ${ }^{104}$ and the existence of initigating circum-

98. Id. at 547, 638 P.2d at 1316, 179 Cal. Rptr. at 919.

99. Dixon v. State Bar, 32 Cal. 3d 728, 736, 653 P.2d 321, 326, 187 Cal. Rptr. 30, 35 (1982) (upholding interpretation of testimony and characterizations accorded various transactions); Montag v. State Bar, 32 Cal. 3d 721, 725, 652 P.2d 1370, 1372, 186 Cal. Rptr. 894, 896 (1982) (record supported finding that petitioner had not been under duress when he perjured himself); Athearn v. State Bar, 32 Cal. 3d 38, 43, 648 P.2d 950, 952, 184 Cal. Rptr. 728, 730 (1982) (facts supported finding that petitioner had not complied with CAL. CT. R. 955); Doyle v. State Bar, 32 Cal. 3d 12, 21, 648 P.2d 942, 947, 184 Cal. Rptr. 720, 725 (1982) (facts supported finding that petitioner had lied); In re Schwartz, 31 Cal. 3d 395, 400, 644 P.2d 833, 836, 182 Cal. Rptr. 640, 643 (1982) (facts supported finding that petitioner lad committed acts involving inoral turpitude).

100. See, e.g., Dixon v. State Bar, 32 Cal. 3d 728, 736, 653 P.2d 321, 326, 187 Cal. Rptr. 30, 35 (1982) (court reluctant to reverse state bar findings that are based primarily on testimonial evidence); In re Schwartz, 31 Cal. 3d 395, 399-400, 644 P.2d 833, 835-36, 182 Cal. Rptr. 640, 642-43 (1982) (petitioner has burden of proof to show that state bar's findings are not supported by the evidence); Jackson v. State Bar, 23 Cal. 3d 509, 512, 591 P.2d 47, 49, 153 Cal. Rptr. 24, 26 (1979) (bar's findings entitled to great weight).

101. Cal. Bus. \& Prof. Code $\S \S 6082,6084$ (West 1974).

102. Id. See 1 B. WrTKn, supra note 11, Attorneys $\$ \$ 270,272-273$ (collecting cases where the suprenie court changed recommended discipline).

103. For example, the state bar may recommend discipline for violations of the Rules of Professional Conduct by suspensions not exceeding three years. CAL. Bus. \& Prof. CoDe $\$ 6077$ (West 1974). Attorneys convicted of crimes involving inoral turpitude are usually disbarred. In re Schwartz, 31 Cal. 3d 395, 401, 644 P.2d 833, 837, 182 Cal. Rptr. 640, 644 (1982); CAL. Bus. \& PRof. CODE $\$ 6077$ (West 1974). In addition to these maximun penalties, the court uses a range of discipline including reprovals and countless combinations of suspension and probation. For examples of the wide range of discipline imposed, see cases cited supra note 95.

104. In re Schwartz, 31 Cal. 3d 395, 401,644 P.2d 833, 836, 182 Cal. Rptr. 640, 643 (1982). 
stances. ${ }^{105}$ Although there is case law on each of these factors, the appropriate level of discipline cannot be reduced to a formula that will serve as useful precedent. ${ }^{106}$ Because the discipline depends on the circumstances, precedents concerning the appropriate discipline for a given offense will suggest only a range of possible sanctions. ${ }^{107}$

In eight of the 1982 cases, the discipline imposed by the state bar was at issue, ${ }^{108}$ and in four of these cases the supreme court imposed a sanction different froin that recommended by the bar court. ${ }^{109}$ In Dixon v. State Bar, ${ }^{110}$ for example, the attorney had committed ten separate violations involving six rules or statutes, and three chents. ${ }^{11}$ Although the supreme court discussed the value of prior cases as a guide to imposmg discipline, it concluded that "the extent of discipline does not derive from a 'fixed formula,' but rather is determined froin a balanced consideration of the relevant factors."112 After discussing the actions of previous petitioners, the court in Dixon imposed a more severe sanction than that imposed by the bar court. ${ }^{113}$ The necessarily ad hoc manner in which discipline was imposed in Dixon is characteristic of most disciplinary cases. ${ }^{114}$

Many cases where the appropriateness of discipline is at issue turn on the existence of mitigating circumstances. ${ }^{115}$ The court's listing of

105. Bernstein v. State Bar, 6 Cal. 3d 909, 919, 495 P.2d 1289, 1294-95, 101 Cal. Rptr. 369, $374-75$ (1972). See infra note 115 and accompanying text.

106. Silver v. State Bar, 13 Cal. 3d 134, 146, 528 P.2d 1157, 1164, 117 Cal. Rptr. 821, 829 (1974).

107. See The Supreme Court of California, 1972-1973, supra note 72, at 617.

108. Dixon v. State Bar, 32 Cal. 3d 728, 738-40, 653 P.2d 321, 327-29, 187 Cal. Rptr. 30, 36-38 (1982); Montag v. State Bar, 32 Cal. 3d 721, 726-27, 652 P.2d 1370, 1372-73, 186 Cal. Rptr. 894, 896-97 (1982); Athearn v. State Bar, 32 Cal. 3d 38, 46, 648 P.2d 950, 953-54, 184 Cal. Rptr. 728, 731-32 (1982); Doyle v. State Bar, 32 Cal. 3d 12, 23-25, 648 P.2d 942, 948-49, 184 Cal. Rptr. 720, 726-27 (1982); Gordon v. State Bar, 31 Cal. 3d 748, 758, 647 P.2d 137, 142, 183 Cal. Rptr. 861, 866 (1982); Ambrose v. State Bar, 31 Cal. 3d 184, 192-96, 643 P.2d 486, 490-92, 181 Cal. Rptr. 903, 907-09 (1982); Garlow v. State Bar, 30 Cal. 3d 912, 916-17, 640 P.2d 1106, 1108-09, 180 Cal. Rptr. 831, 833-34 (1982); Price v. State Bar, 30 Cal. 3d 537, 548, 638 P.2d 1311, 1317, 179 Cal. Rptr. 914, 920 (1982).

109. Dixon v. State Bar, 32 Cal. 3d 728, 740, 653 P.2d 321, 329, 187 Cal. Rptr. 30, 38 (1982) (increase); Gordon v. State Bar, 31 Cal. 3d 748, 758, 647 P.2d 137, 142, 183 Cal. Rptr. 861, 866 (1982) (increase); Ambrose v. State Bar, 31 Cal. 3d 184, 196, 643 P.2d 486, 492, 181 Cal. Rptr. 903, 909 (1982) (increase); Price v. State Bar, 30 Cal. 3d 537, 550, 638 P.2d 1311, 1318, 179 Cal. Rptr. 914, 921 (1982) (decrease).

110. 32 Cal. 3d 728, 653 P.2d 321, 187 Cal. Rptr. 30 (1982).

111. Id. at 733-35, 653 P.2d at 324-26, 187 Cal. Rptr. at 33-35.

112. Id. at 738, 653 P.2d at 327, 187 Cal. Rptr. at 36 (quoting Silver v. State Bar, 13 Cal. 3d 134, 146, 528 P.2d 1157, 1165, 117 Cal. Rptr. 821, 829 (1974)).

113. Id. at 739-40, 653 P.2d at 328, 187 Cal. Rptr. at 37-38.

114. See 1 B. Wrrkn, supra note 11, Attomeys $\$ 270$, at 274-85 (After comparing numerous cases involving moral turpitude, Witkin concludes that "[t]he decisions reveal little pattern in discipline imposed.").

115. Mitigating circumstances were an issue in several of the 1982 cases. In re Mudge, $33 \mathrm{Cal}$. 3d 152, 654 P.2d 1307, 187 Cal. Rptr. 779 (1982); Doyle v. State Bar, 32 Cal. 3d 12, 648 P.2d 942, 
mitigating factors neither develops the law nor provides useful precedent. As an einpirical matter, any given set of circumstances is unlikely to reappear. And even if a particular mitigating factor does appear in another case, the weight it should be given will be tied to the specific facts of the case.

Developinent of the law requires that a court decide new issues or resolve conflicting interpretations of the law. Since no other court in California reviews attorney discipline cases, the law in this area develops only when the supreme court decides new issues or alters existing law. By automatically granting petitions for review in disciplinary cases, the court in effect places control of its docket in the hands of those disciplined attorneys who choose to appeal. An attorney who has been disciplined will seek review if it is in his interest, irrespective of the legal significance of his case. Since the supreme court regularly finds that over ninety percent of the nondisciplinary cases do not warrant review, ${ }^{116}$ it is unreasonable to expect that a high percentage of the disciplinary cases are legally significant. The highly factual nature of disciplinary cases and their limited legal significance thus suggest that direct review of attorney discipline cases is inappropriate.

\section{III \\ A Proposed Solution: Transfer to the COURTS OF APPEAL}

The Clark Report made a series of recommendations regarding the organization of attorney discipline systeins. ${ }^{17}$ The Clark Report, however, focused exclusively on the need for attorney discipline at a time when it was perceived as inadequate ${ }^{118}$ while failing to consider the larger problem of limited judicial resources. Thirteen years after the report, both the number of attorneys in California and the workload of the supreme court have increased dramatically. ${ }^{19}$ These changes argue against the court's present practice of hearing virtually

184 Cal. Rptr. 720 (1982); Gordon v. State Bar, 31 Cal. 3d 748, 647 P.2d 137, 183 Cal. Rptr. 861 (1982); In re Schwartz, 31 Cal. 3d 395, 644 P.2d 833, 182 Cal. Rptr. 640 (1982); Ambrose v. State Bar, 31 Cal. 3d 184, 643 P.2d 486, 181 Cal. Rptr. 903 (1982). The facts of In re Mudge presented the court with several mitigating circumstances: tcrmination of the attorney's marriage, full restitution of the misappropriated funds, and fifteen years of practice without a disciplinary record. 33 Cal. 3d 152, 155-56, 654 P.2d 1307, 1309-10, 187 Cal. Rptr. 779, 781-82 (1982). Noting that "[m]isappropriation of client's funds . . . warrants disbarment in the absence of mitigating circumstances," id. at 157, 654 P.2d at 1310, $187 \mathrm{Cal}$. Rptr. at 782, the court ordered a two-year suspension.

116. Simce fiscal year 1971-1972, the supreme court has granted less than $9.5 \%$ of the petitions for review filed in any year. 1982 Jud. Councli CAL. ANN. ReP. 49 table IV.

117. Clark REPORT, supra note 34, at 19-192.

118. Id. at 2.

119. See supra notes $31-33$ and accompanying text. 
all disciplinary appeals. ${ }^{120}$

Although in most states, as in California, the highest state court reviews disciplinary cases, ${ }^{121}$ there are a number of states that do not take this approach. Eight states have discipline by the bar or lower courts that is final unless appealed to the highest court. ${ }^{122}$ Tennessee, for example, allows an attorney to appeal the bar's recommendation to the Chancery Court; the order of the Chancery Court becomes the final order unless there is an appeal to the Tennessee Supreme Court. ${ }^{123}$ In North Carolina discipline by the state bar is final. ${ }^{124}$ The superior courts of Connecticut have final authority to discipline attorneys. ${ }^{125}$ In Maine a single justice of the supreme court nnay hold hearings and render judginent; the respondent may appeal, however, and have the entire court hear the case. ${ }^{126}$

This Comment proposes that in California primary review of disciplinary cases and initial development of disciplinary law should be left to the courts of appeal. The supreme court should review disciplinary cases only when it sees a need to correct or reconcile the positions taken by the courts of appeal. This result could be accomplished through the transfer authority given the California Supreme Court by the California Constitution.

\section{A. The Transfer Authority}

Article VI, section 12, of the California Constitution provides that the supreme court may, before decision, transfer a cause froin itself to a court of appeal, ${ }^{127}$ giving that appellate court jurisdiction over the cause. ${ }^{128}$ The transfer authority has been used to transfer cases from the supreme court to the courts of appeal even when the constitution granted the supreme court appellate jurisdiction over the case. In

120. See supra notes $31-33$ and accompanying text.

121. See supra note 34 and accompanying text.

122. In Alabama, Arkansas, Florida, Mississippi, Tennessee, Texas, Virginia, and Wisconsm, discipline is final unless appealed to the highest court. NATIONAL CENTER FOR Professional Responsibiltry, STate Disciplinary ENForcement SYstems Structural SuRveY 1, 10, 28, $76,142,145,154,163$ (1980). In contrast, in California discipline other than reprimands may only be recommended to the supreme court, which orders the discipline. Id at 13.

123. Id. at 142.

124. Id. at 115 .

125. Id. at 19.

126. Id. at 60 . The District of Columbia employs a similar system. A panel of three judges reviews all discipline other than disbarment. Recommendations of disbarment are handled by the court en banc. Id. at 25 .

127. Article VI, $\S 12$ of the California Constitution provides in part: "The Supreme court may, before decision becomes final, transfer to itself a cause in a court of appeal. It may, before decision, transfer a cause from itself to a court of appeal or from one court of appeal or division to another." CAL. ConsT. art. VI, § 12.

128. "The Court to which a cause is transferred has jurisdiction." Id. 
Smith v. Tristam, ${ }^{129}$ for example, the court of appeal held that while the California Constitution required all appeals in equity to be taken directly to the supreme court, such an appeal in equity was properly before the court of appeal after transfer from the supreme court. ${ }^{130}$ The transfer authority is thus not limited by other constitutional provisions that direct causes be heard by the supreme court. ${ }^{131}$ A fortiori, the transfer authority is not limited by statutes such as the State Bar Act that direct the supreme court to hear certain cases.

The use of the transfer authority in state bar matters is well estabbished. Prior to the enactment of the State Bar Act, the supreme court used the transfer authority to transfer bar admission cases froin itself to the courts of appeal, ${ }^{132}$ and from the courts of appeal to itself. ${ }^{133}$ In transferring bar admission cases, the court held that petitions for admission were "causes" within the ineaning of the transfer authority. ${ }^{134}$ More recently, Justice Newman advocated that admission cases be transferred to the courts of appeal under the transfer authority. ${ }^{135}$ The broad definition of "cause," and the court's previous use of the transfer clause to transfer admission cases demonstrate the supreme court's authority to transfer disciplinary cases to the courts of appeal.

Although the legislature established the present disciplinary system, a modification of the system by the supreme court would be entirely legitimate. The supreme court's power over the disciplinary process extends to all steps in the system. ${ }^{136}$ Moreover, included within the State Bar Act is a provision that the Act is not to be construed as limiting or altering the powers of the supreme court. ${ }^{137}$ Thus, transfer

129. 130 Cal. App. 750, 20 P.2d 770 (1933).

130. Id. at $751,20 \mathrm{P} .2 \mathrm{~d}$ at 770 .

131. Witkin states that the transfer authority permits the supreme court to transfer death penalty cases even though the constitution gives the supreme court original jurisdiction over these cases. 1 B. WITKIN, supra note 11, Courts $\$ 218$.

132. See, e.g., In re Cate, 197 Cal. 796, 797, 241 P. 95, 96 (1925).

133. See, e.g., In re Stevens, 197 Cal. 408, 414, 241 P. 88,90 (1925).

134. Id. at 411-12, 241 P. at 89-90 (1925); In re Wells, 174 Cal. 467, 471, 163 P. 657,659 (1917) ("This provision has always been understood to apply to all cases, matters, and proceedimgs of every description.").

135. Bib'le v. Committee of Bar Examiners, 26 Cal. 3d 548, 556, 606 P.2d 733, 738, 162 Cal. Rptr. 426, 431 (1980) (Newman, J., dissenting) (Justice Newman's statement that admissions cases should be transferred to the courts of appeal appears ouly in the California Reports advance sheets), cert. denied, 449 U.S. 860 (1980). See also Chilton, Appellate Court Reform: The Premature Scalpel, 48 CAL. ST. B.J. 393, 468 (1973):

State Bar matters should not be appealable directly to the Supreme Court. Decisions of other hicensing boards are reviewed by administrative mandamus; there would appear no sufficient reason for the extraordinary treatment given lawyers. These cases often involve voluminous records and clashes over trivial points; the Supreme court should not have to waste its precious time disciplining the bar.

136. Brotsky v. State Bar, 57 Cal. 2d 287, 301, 368 P.2d 697, 704, 19 Cal. Rptr. 153, 160 (1962).

137. Cal. Bus. \& Prof. Code $\S 6087$ (West 1974). See Brotsky v. State Bar, 57 Cal. 2d 287, 300-01, 368 P.2d 697, 704, 19 Cal. Rptr. 153, 160 (1962). 
of cases to the courts of appeal would be a valid exercise of the supreme court's inherent power over attorney discipline and over its own workload.

\section{B. The Workings of Transfer}

The transfer authority should be routinely used by the supreme court to transfer disciplinary cases to the courts of appeal. The courts of appeal should review uncontested inatters and hear arguments when an attorney requests a hearing or the courts find the discipline improper. If either the state bar or the respondent is dissatisfied with the action of the court of appeal, either party could file a petition for review by the supreine court. ${ }^{138}$

The supreme court would then grant a writ of review in disciplinary actions based on the same criteria it uses in granting review of other decisions: ${ }^{139}$ the supreme court would review only cases in which an important legal question had to be resolved. As in all matters, the supreme court would also have the option of decertifying any court of appeal opimion. The court would be free to grant review in a higher percentage of disciplinary cases than it does with other cases if needed.

\section{The Advantages of Transfer}

The major consequence of this proposal would be to allow the supreme court to place on its docket only those disciplinary cases of potential legal significance. Two advantages would flow from this consequence. First, the proposal would save the court a significant amount of time. Second, and related, it would increase the ability of the court to perform its basic role of supervising the development of California law.

While it is impossible to predict exactly how much time would be saved by shifting the review of state bar matters to the courts of appeal, it would certainly free the supreine court of a significant anount of work. The amount of time saved would imclude not just the time spent on disciplinary cases that lead to published opinions, but also the time spent reviewing all but the most minor discipline recommended by the state bar. The supreme court reviews all suspensions and disbarments recommended by the bar court. ${ }^{140}$ This involves reviewing the record

138. In re Stevens, 197 Cal. 408, 414, 241 P. 88, 90 (1925).

139. See supra notes 11-15 and accompanying text.

140. See Brotsky v. State Bar, 57 Cal. 2d 287, 301, 368 P.2d 697, 704, 19 Cal. Rptr. 153, 160 (1962) ("IN]o disciplinary action taken [by the state bar] shall be final without recourse to review by the Supreme Court. By section 6078 the Board of Governors of the State Bar may only recommend suspension or disbarment. Final action can only be taken by this court.") (emphasis in origimal). 
of the state bar court in each of these cases. ${ }^{141}$ In 1982 the state bar recommended 105 suspensions and disbarments to the supreme court. ${ }^{142}$ When no petition for review is inade, the court's examimation of the bar court's actions is evidenced by indications that one or more justices would have imposed a inore severe discipline. ${ }^{143}$ The most visible result of the court's review of such recommendations occurs in cases involving petitions for review that are filed and granted only after the supreme court informs the attorney that it is considering the imposition of a more severe discipline than that recommended by the bar court. ${ }^{144}$

Of the 105 disciplinary recommendations made by the state bar in 1982, the supreme court heard full argument in ten cases. ${ }^{145}$ In such cases, not only must the court review the record, but the court must consider the briefs and oral arguinents of the attorney and the state bar. ${ }^{146}$ Moreover, the court publishes all of its opinions. ${ }^{147}$ Thus, these cases require more attention from the justices themselves than review of cases where no petition for review is granted.

Membership in the state bar currently exceeds 80,000 attorneys and each year approximately 6,000 new attorneys are admitted. ${ }^{148}$ Although statistics on disciplinary actions are not consistently available, the number of disciplinary actions seems to have risen with the number

141. Browne v. State Bar, 45 Cal. 2d 165, 169, 287 P.2d 745, 747 (1955).

142. Letter from the State Bar of California to Richard Wallace (Nov. 28, 1983) (on file with the California Law Review). In 1980 and 1981 the number of suspensions and disbarments recommended to the supreme court were 66 and 92 respectively. Id.

143. See, e.g., In re Flores, No. Bar Misc. 4566 (Cal. Sup. Ct. Feb. 2, 1983) (Kaus, J.); In re Tarver, No. Bar Misc. 4559 (Cal. Sup. Ct. petition to set aside interim suspension demied Jan. 13, 1983) (Mosk, J., dissenting from demial of petition); In re Hill, No. Bar Mise. 4523 (Cal. Sup. Ct. Dec. 15, 1982) (Richardson, J., of the opinion that more severe discipline should have been imposed); In re Slaten, No. Bar Misc. 4555 (Cal. Sup. Ct. Nov. 10, 1982) (Richardson, J.) (more severe discipline should have been iniposed).

144. See In re Mudge, 33 Cal. 3d 152, 154, 654 P.2d 1307, 1308, 187 Cal. Rptr. 779, 780 (1982); Dixon v. State Bar, 32 Cal. 3d 728, 732, 653 P.2d 321, 323, 187 Cal. Rptr. 30, 32 (1982); Gordon v. State Bar, 31 Cal. 3d 748, 751, 647 P.2d 137, 138, 183 Cal. Rptr. 861, 862 (1982); Finch v. State Bar, 28 Cal. 3d 659, 662, 621 P.2d 253, 254-55, 170 Cal. Rpir. 629, 630-31 (1981); Giovanazzi v. State Bar, 28 Cal. 3d 465, 471, 619 P.2d 1005, 1008, 169 Cal. Rptr. 581, 584 (1980) ("This court has repeatedly held that it is for it and not the board to fix the discipline in any particular case." The court imposed a more severe discipline after the attorney and the state bar had stipulated the recommended discipline and findings of fact.).

145. See supra note 95.

146. Cal. Bus. \& Prof. Code $\S 6082$ (West 1974); Cal. Ct. R. 952(a).

147. Cal. CT. R. 976.

148. As of Nov. 28,1983 there were 80,801 active and 8934 inactive members of the California State Bar. Letter from the State Bar of California to Richard Wallace (Nov. 28, 1983) (on file with the California Law Review). Between 1972 and 1982 the state bar added 50,982 new members of the state bar. Id. 
of attorneys. ${ }^{149}$ Under the court's present policy of automatically reviewing all but the most minor disciplinary actions, any increase in the number of such actions has an immediate and direct effect on the court's workload. If more petitions for review are filed in cases where the court has discretion to grant review, the court can respond by being 1nore selective in the cases it hears. However, without some change in the court's practice of directly reviewing disciplinary cases, the court will need to devote an mcreasing amount of time to disciplinary matters. ${ }^{150}$

A second and more important advantage of eliminating direct review of disciplinary cases is that it would allow the court to better perform its basic role of supervising the developinent of California law. Since the supreme court has a limited capacity to review cases, it should confine its work to tasks that only it can perforn. Only the supreme court can review the tremendous volume of new law generated by the California Courts of Appeal. And as the caseload of the courts of appeal grows, so does the need for supervision by the supreme court. ${ }^{151}$ Therefore, each year, the court is obliged to grant hearings in a declining percentage of cases. ${ }^{152}$ In addition, the increased number of petitions for hearing forces the court to deny petitions for hearing in cases that it would have considered significant enough to warrant a hearimg in previous years. ${ }^{153}$ Simply reviewing the increased number of petitions for hearing takes time that the court used to spend liearing

149. The number of disciplinary proceedings filed against attorneys in the supreme court has varied from year to year, but the overall trend has been towards an increasing number of petitions.

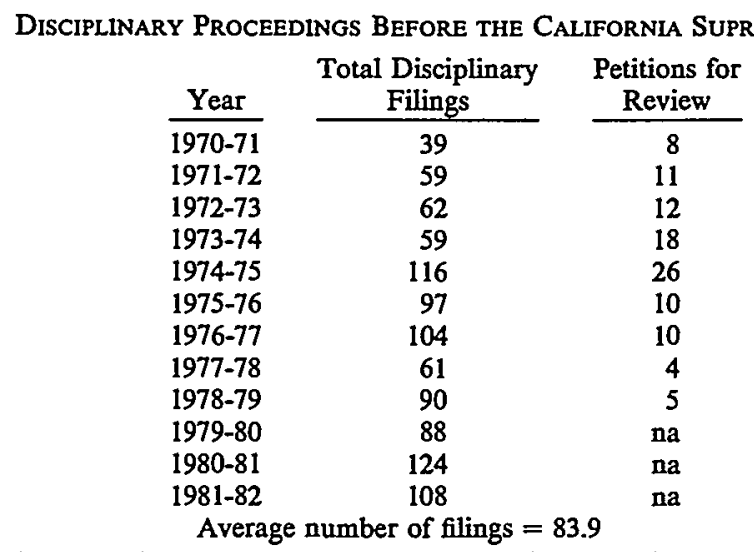

1972 Jud. Council Cal. ANN. Rep. 65; 1973 Jud. Council Cal. ANN. Rep. 173; 1974 Jud. Council Cal. ANN. Rep. 95; 1976 Jud. Council CAL. ANN. Rep. 85 table III; 1978 Jud. Councll Cal. AnN. Rep. 63 table III; 1980 Jud. Councll Cal. ANN. Rep. 51 table III.

150. Comment, supra note 10 , at $789-90$.

151. Id. at 789.

152. 1983 Jud. Councll CAL. ANN. Rep. 81 table VI.

153. Comment, supra note 10 , at 789 . 
cases and guiding the developinent of the law. Thus, eliminating the burden of automatic review of disciplinary actions would enable the court to hear more cases of importance to California law.

\section{CONCLUSION}

The supreme court possesses the inherent power to shape the process of attorney discipline and bears the ultimate responsibility for the integrity of the bar. Although California's present practice has been recommended as a model disciplinary system, its use of the supreme court's resources is not justified. Only the supreme court is able to guide the development of California law. Accordingly, duties assigned to the supreme court that conflict with this task should be carefully scrutinized.

The present system could have been justified in an earlier period when fewer attorneys practiced in California and the courts of appeal produced fewer opimions. The growing number of attorneys and petitions for review has made automatic review of attorney discipline cases an unaffordable luxury. Transfer of disciplinary cases to the courts of appeal would mamtain judicial review of all actions of the bar court and preserve supreme court review of important disciplinary issues while freeing the supreme court to better perform its function of overseemg the developinent of California law.

Richard Green Wallace*

- A.B. 1981, University of California, Berkeley; third-year student, Boalt Hall School of Law, University of California, Berkeley. 